Theories \& Applications, the International Edition

Printed Version: (ISSN 2090-5262)

Online Version: (ISSN 2090-5270)

March 2013, Volume 3, No. 1 Pages (60 - 77)

\title{
The Effect of an Educational Program Using a Computerized Systematic Approach on Learning Some Skills of Volleyball
}

\author{
Mostafa El-Nouby Mohamed Omar*, Eman Sayed Ahmed Mohamed**, Ahmed Mohamed Abdelaziz \\ Mohamed $^{* * *}$
}

\section{* Assistant Professor, Curriculum and Physical Education Department, Faculty of Education, South Valley University \\ ** Lecturer, Curriculum and Physical Education Department, Faculty of Education, Asyut University. *** Lecturer, Curriculum and Physical Education Department, Faculty of Education, Minia University.}

\section{Introduction and Research Problem}

$\mathrm{T}$ he educational policy in Egypt has always focused on a number of issues such as curriculum development, teaching, promoting educational activities, teacher re-qualification, introducing new technology and diversifying the sources of knowledge. Despite the increased awareness of the importance of teaching in improving and developing society, the continuous efforts to enhance and reform teaching in the light of local and world changes, and the continuous work towards curriculum development, graduates of public education institutions still need to exert greater efforts in order to improve the educational process.

One of the major contemporary educational challenges is the inadequacy of the teaching process, a fact attributable to the failure to view education as a system consisting of related components that work together to achieve a common target. Studies aiming at developing the teaching process usually start with one component, namely the content of the curriculum, with no apparent link with other components, such as aims of the curriculum, evaluation methods, etc, thus attending to developing particular components rather than the curriculum as a whole (52: $154-156),(48$ : $145),(47: 6,7)$.

Recently, a new approach based on a systematic change in the teaching curriculum, has been introduced, according to which teaching is viewed as one comprehensive system consisting of several sub-systems inter-related in such a manner as to serve one common purpose. The system involves interactive, overlapping and dynamic relationships between its parts. It is in a state of constant dynamic change, influenced both by external inputs from the surrounding environment and internal inputs inherent in the system. The system benefits from outputs and feedback as well. Organization, growth and accumulated information also play major roles in the system. (21:24), (32: 125).

The systematic approach can be effectively used in the different stages of education to advance the cognitive, skillful and emotional aspects of the learning process in a harmonious, congruent manner. Identifying what learners know and what they need to know, the systematic approach seeks to create opportunities that would facilitate learning and translate the learning outputs into measurable objectives. The approach also stimulates learners, improves their skills of solving problems and develop their higher skills of thinking (49: 24), (50: 88), (53: 125).

Further studies on volleyball teaching and learning must explore the cognitive as well as the professional motives of using the systematic approach and how it can be used to develop volleyball skills. Compared to efforts exerted so far in volleyball teaching, progress on the skilful level of students was unsatisfactory. The systematic approach would hopefully contribute to the acquisition by students of the necessary skills and benefit from the contents of volleyball curriculum. A computerized systematic approach of the skillful learning of volleyball would certainly be more effective, will take into account the individual differences between 
learners and help them acquire experience that would save time and effort.

\section{Research Objective}

This research aims at designing an educational program using a computerized systematic approach of volleyball skills [throwing the ball from the top to the front, throwing it from the bottom by hands together, sending it from the bottom opposite] for freshmen in the Faculty of Physical Education, South Valley University and determining its effect on:

1- Skilful learning

2- Cognitive achievement

3- The emotional aspect of the student's character

\section{Research Hypotheses}

1- There are statistically significant differences between the score means of the 2 post measurements in the control and experimental groups in learning volleyball skills addressed by this paper, favoring the experimental group.

2- The percentage of change in learning volleyball skills is higher in the experimental group than in the control group.

3- There are statistically significant differences between the score means of the 2 post measurements for the control and experimental groups in the cognitive achievement of volleyball skills addressed by this paper, favoring the experimental group

4- Percentage of change in the cognitive achievement of volleyball skills is higher in the experimental group than in the control group.

5- There are statistically significant differences in the emotional aspect of the experimental group students favoring the use of the computerized systematic approach in learning volleyball skills addressed in this paper.

\section{Research Procedures and Plan}

To achieve the research objective and test its hypotheses, the following procedures were taken:

\section{Methodology}

The experimental method was used, being suitable for this type of study. The method was applied to two groups: an experimental group and a control group, and pre- and postmeasurements were taken of both groups.

\section{Research Community and Sample}

The research community included freshmen in the faculty of physical education, South Valley University in the 2010 / 2011 academic year (N $=232$ students). A sample of 60 students was randomly selected, constituting about $25 \%$ of the research community. The sample was divided into two equal groups, each of 30 students. The suggested educational program, based on the computerized systematic approach in learning volleyball skills, was applied to one of the groups (the experimental group), while the conventional programme, based on explanation and model performance, was used with the other (control group). The following categories were excluded:

1- Failing students and students who did not attend regularly

2- Students enrolled in sporting clubs and those who have already won sports championships.

\section{The Normal Distribution of the Sample}

Researchers made sure that the distribution of sample subjects was normal for both groups [the experimental and the control groups] in the light of the following variables: growth rates (age, height and weight), physical changes, skillful variables and cognitive acquisition [Table ([1)]. 
Table (1)

Mean, median, standard deviation and coefficient of torsion of age, height, weight, physical tests, skill tests, and cognitive acquisition tests of the volleyball skills in the total sample of the control and the experimental groups

\begin{tabular}{|c|c|c|c|c|c|}
\hline \multicolumn{6}{|c|}{$\mathrm{N}=60$} \\
\hline Variables & $\begin{array}{l}\text { Measurement } \\
\text { unit }\end{array}$ & Mean & $\begin{array}{l}\text { Standard } \\
\text { deviation }\end{array}$ & Median & $\begin{array}{l}\text { Coefficient } \\
\text { of torsion }\end{array}$ \\
\hline Age & Year & 17.60 & .72 & 17.00 & 2.50 \\
\hline Height & Centimeter & 171.13 & 2.15 & 171.00 & .18 \\
\hline Weight & Kilogram & 69.63 & 1.81 & 70.00 &.-61 \\
\hline $\begin{array}{l}\text { Running } 30 \mathrm{~m} \text { from } \\
\text { starting movements }\end{array}$ & Second & 4.33 & .24 & 4.38 &.-62 \\
\hline $\begin{array}{l}\text { Bending the trunk } \\
\text { forwards from the } \\
\text { standing position }\end{array}$ & Centimeter & 18.43 & .96 & 18.50 &.-11 \\
\hline $\begin{array}{l}\text { Throwing and } \\
\text { receiving the ball }\end{array}$ & Degree & 17.23 & 1.17 & 17.00 & .59 \\
\hline Shuttle running & Second & 12.10 & .10 & 1.86 & .81 \\
\hline $\begin{array}{l}\text { Broad jump from } \\
\text { the } \\
\text { position }\end{array}$ & Meter & 1.87 & .10 & 1.86 & .45 \\
\hline $\begin{array}{l}\text { Shooting with the } \\
\text { hand to the } \\
\text { overlapping circles }\end{array}$ & Degree & 6.40 & .67 & 6.50 & .45 \\
\hline $\begin{array}{l}\text { Accuracy of } \\
\text { passing over the } \\
\text { ball to the wall }\end{array}$ & Degree & 20.80 & 1.03 & 20.50 & .87 \\
\hline $\begin{array}{l}\text { Passing from the } \\
\text { bottom of the } \\
\text { ballot the wall for } \\
30 \text { seconds }\end{array}$ & Degree & 8.37 & 1.97 & 18.00 & .56 \\
\hline $\begin{array}{l}\text { AAPHER test to } \\
\text { send from the } \\
\text { bottom }\end{array}$ & Degree & 20.17 & 1.34 & 20.50 &.-74 \\
\hline $\begin{array}{l}\text { Cognitive } \\
\text { acquisition }\end{array}$ & Degree & 13.30 & 1.44 & 13.50 &.-42 \\
\hline
\end{tabular}

Table (1) shows that coefficient of torsion of the variables ranged between 2.50 and $0.74(3+,-3]$. This indicates the normal frequency distribution of the research sample. 


\section{Equivalency of the research groups}

The equivalency between the two groups in the variables of age, height, weight, physical tests, skill tests, and cognitive acquisition test in volleyball was found, [Tables (2), (3) and (4).

\section{Table (2)}

Significance of differences between the two means of degrees for the control and experimental groups in the variables of age, height and weight

$$
\mathrm{N}=60
$$

\begin{tabular}{|l|l|l|l|l|l|l|}
\hline Variables & Measurement unit & \multicolumn{2}{|l|}{$\begin{array}{l}\text { Experimental } \\
\text { group }\end{array}$} & \multicolumn{2}{l|}{$\begin{array}{l}\text { Controlling } \\
\text { Group }\end{array}$} & 'T' value \\
\hline Age & Year & 17.60 & .72 & 17.73 & .69 & .70 \\
\hline Height & Centimeter & 171.13 & 2.15 & 171.40 & 2.19 & .47 \\
\hline Weight & Kilogram & 69.63 & 1.81 & 69.07 & 2.00 & 1.12 \\
\hline
\end{tabular}

Tabular ' $\mathrm{T}$ ' value at the level of $(0.05)=2.021$

According to Table (2), there are no statistically significant differences between the two means of measurement degrees for the control and experimental groups in the variables of age,

Table (3) height and weight, whereas the calculated "T" value is less than the tabular "T" value at the level of (0.05), this refers to the equivalency of these variables.

Significance of differences between the two means of the measurement degrees for the control and experimental groups in the Physical tests

$$
\mathrm{N}=60
$$

\begin{tabular}{|c|c|c|c|c|c|c|}
\hline \multirow{2}{*}{$\begin{array}{l}\text { Physical tests } \\
\begin{array}{l}\text { Running } 30 \mathrm{~m} \text { from starting } \\
\text { movements }\end{array}\end{array}$} & \multirow{2}{*}{\begin{tabular}{|l|}
$\begin{array}{l}\text { Measurement } \\
\text { unit }\end{array}$ \\
Second \\
\end{tabular}} & \multicolumn{2}{|c|}{ Control groups } & \multicolumn{2}{|c|}{$\begin{array}{l}\text { Experimental } \\
\text { group }\end{array}$} & \multirow{2}{*}{$\begin{array}{l}\text { Calculated } \\
\text { "T" value } \\
.34\end{array}$} \\
\hline & & 4.35 & .20 & 4.33 & .24 & \\
\hline $\begin{array}{l}\text { Bending the trunk forwards } \\
\text { from the standing position }\end{array}$ & Centimeter & 18.50 & 1.80 & 18.43 & 1.96 & .14 \\
\hline $\begin{array}{l}\text { Throwing and receiving the } \\
\text { ball }\end{array}$ & Degree & 17.47 & 1.14 & 17.23 & 1.17 & .79 \\
\hline Shuttle running & Second & 12.16 & .33 & 12.10 & .26 & .77 \\
\hline $\begin{array}{l}\text { Broad jump from the standing } \\
\text { position }\end{array}$ & Meter & 1.88 & .10 & 1.87 & .10 & .38 \\
\hline $\begin{array}{l}\text { Shooting with the hand to the } \\
\text { overlapping circles }\end{array}$ & Degree & 6.50 & .57 & 6.40 & .67 & .61 \\
\hline
\end{tabular}

Tabular " $\mathrm{T}$ " value at the level $(0.05)=2.021$

Table (3) shows that there are no statistically significant differences between the two means of measurement degrees for the experimental and control groups in the physical tests, whereas the calculated $(\mathrm{T})$ value is less than the tabular (T) value at the level (0.05) This indicates the equivalency of the two groups in theses tests. 
Table (4)

Significance of differences between the two means of the pre measurement degrees for the control and experimental groups in the skill tests and cognitive acquisition test

$\mathrm{N}=60$

\begin{tabular}{|c|c|c|c|c|c|c|}
\hline Test & $\begin{array}{l}\text { Measurement } \\
\text { unit }\end{array}$ & \multicolumn{2}{|c|}{$\begin{array}{l}\text { Experimental } \\
\text { group }\end{array}$} & \multicolumn{2}{|c|}{ Control groups } & $\begin{array}{l}\text { Calculated } \\
\text { "T" value }\end{array}$ \\
\hline $\begin{array}{l}\text { Accuracy of passing } \\
\text { over the ball to the } \\
\text { wall }\end{array}$ & Degree & 20.80 & 1.03 & 20.8 & 1.39 & .09 \\
\hline $\begin{array}{l}\text { Passing from the } \\
\text { bottom of the ballot } \\
\text { the wall for } 30 \\
\text { seconds }\end{array}$ & Degree & 18.37 & 1.97 & 18.43 & 1.83 & .12 \\
\hline $\begin{array}{l}\text { AAPHER test to send } \\
\text { from the bottom }\end{array}$ & Degree & 20.17 & 1.34 & 20.03 & 1.07 & .44 \\
\hline Cognitive acquisition & Degree & 13.30 & 1.44 & 13.23 & 1.38 & .19 \\
\hline
\end{tabular}

Tabular ' $\mathrm{T}$ ' value at the level $(0.05)=2.021$

Table (4) shows that there are no statistically significant differences between the means of the pre-measurement degrees for the experimental and control groups in skill tests and cognitive acquisition test, whereas the calculated (T) value is less than the Tabular ' $\mathrm{T}$ ' value at the level $(0.05)=2.021$. This indicates the equivalency of both groups in the said tests.

\section{Means of data collecting}

1- Physical tests.

2- Skill tests.

3- Cognitive acquisition test (designed by the researchers).

4- Emotional aspect scale (designed by the researchers).

5- The educational program using the computerized systematic approach (designed by the researchers).

6- A compact disc "CD" prepared by the researchers.

\section{Pilot Studies}

The first pilot study was carried out in the period 24/02/2011 - 06/03/2011 on a sample of 60 students from the same research community but outside the original sample and similar to it, in order to test the tools and devices used in the research, and making sure of their suitability, training the assistants on applying the measurement and finding the scientific coefficients. The second pilot study was carried out in the period $07 / 03 / 2011$ to $08 / 03 / 2011$ on a sample of 30 students from the same research community but outside the original sample and similar to it, in order to try the systematic approach program for volleyball skills through implementation of the program in the educational unit to identify the instructional situation. It was found out that the students have a high ability to use the systematic approach (CD software).

\section{Preparatory Procedures}

A meeting was held for the students of the control and experimental groups on 09/03/2011 to explain the research objectives, how to enter and leave the computer laboratory, how to use the software of the systematic approach, how to deal with the basics instructions, and follow the instructions of the researchers who taught the experimental group students, and also to explain the work system to the control group students. The researchers were satisfied with the understanding of the two groups of the nature of the work assigned to them.

\section{Pre-measurements}


Pre-measurements of the control and experimental groups were taken in the period 10/03/2011 - 12/03/2011.

\section{Procedures}

1- Upon completion of pre-measurements, research was conducted in the period 13/03/2011 - 20/04/2011.

2- Researchers taught the students of the control and experimental groups, using the computerized systematic approach to carryout the research through the following steps:

A- researchers started by writing down names of absent students in the experimental group and going in an orderly manner to the computer laboratory on time. Every student got the software CD to watch and interact with the part determined by the researcher of the systematic approach software.

B- when they finish watching for fifteen minutes, researchers get back the $\mathrm{CD}$, then students leave to the play ground passing by the section of warm up and physical preparation, then they carry out what they saw and interacted with in the program of the systematic approach that is related to volleyball in the educational unit, this will be done in the applied activity under the researchers supervision and guidance.

3- The researchers taught the experimental group by using the computerized systematic approach, and the control groups by the traditional method [explanation and model performance], this was on every Sunday and Wednesday during carrying out the research. This was subject

to the time distribution in the educational units during carrying out the research for the experimental and control groups.
4- $\quad$ Doing the educational units took about a month and half, I mean that the six weeks assigned for doing the research. Educational units were divided into 12 units for each group, two units a week for each of the experimental and control groups, time of each unit was 120 minutes.

5- The organized form and time distribution of the educational unit were as follows:

A- administrative work [5 minutes ]

B- watching the programs [15 minutes]

C- warm up and physical preparation [20 minutes]

D- applied activity [70minutes]

E- conclusion [10 minutes]

6- A number of demonstrators from the faculty of physical education assisted in doing the scientific coefficient coefficients and getting the pre and post measurements.

\section{Post measurement}

Post measurements were taken after applying the research to the experimental and control group just as was done with pre-measurements. Measurements were taken in the period from April 21' 2011 to April 24, 2011.

\section{Statistical treatment}

Data was statistically treated to find the mean, the standard deviation, the median, the correlation coefficient, the coefficient of ease, the coefficient of difficulty, the coefficient of difference, the Kay square, the alpha coefficient and the relative weight. The significance level $[0,05]$ satisfied the researchers. The Microsoft excel and the SPSS softwares were used in the statistical treatment. 
Table (5)

Significance of differences between the mean of the pre and post measurement degrees in the control and experimental group in skill tests

$$
\mathrm{N}=30
$$

\begin{tabular}{|l|l|l|l|l|l|l|l|}
\hline Series & Skill test & $\begin{array}{l}\text { Measure } \\
\text { ment unit }\end{array}$ & $\begin{array}{l}\text { Mean of pre- } \\
\text { measurement }\end{array}$ & $\begin{array}{l}\text { Mean of post } \\
\text { measurement }\end{array}$ & $\begin{array}{l}\text { Standard } \\
\text { deviation }\end{array}$ & $\begin{array}{l}\text { Differen } \\
\text { ce mean }\end{array}$ & $\begin{array}{l}\text { Calculated[ } \\
\text { t] value }\end{array}$ \\
\hline 2 & $\begin{array}{l}\text { Accuracy of } \\
\text { passing } \\
\text { from the top } \\
\text { of the wall }\end{array}$ & Degree & 20,80 & 27,70 & 1,18 & 6,90 & 31,90 \\
\hline $\begin{array}{l}\text { Passing the } \\
\text { from th } \\
\text { bottom f the } \\
\text { wall for 30 } \\
\text { seconds }\end{array}$ & Degree & 18,37 & 24,73 & 2,11 & 6,37 & 16,54 \\
\hline 3 & $\begin{array}{l}\text { AAPHER } \\
\text { for sending } \\
\text { from the } \\
\text { bottom }\end{array}$ & Degree & 20,17 & 29,03 & 1,50 & 8,87 & 32,32 \\
\hline
\end{tabular}

The tabular[t] value at the level of $0,05=1,68$

Table (5) shows that there are statistically significant differences between the mean of the pro and post measurement degrees in the experimental groups in the skill tests favoring

\section{Table (6)}

Significance of differences between the means of the pre and post measurements degree in the control group in the skill tests value is higher than the $[\mathrm{t}]$ value at the level $(0.05)$.

$$
\mathrm{N}=30
$$

\begin{tabular}{|l|l|l|l|l|l|l|l|}
\hline Series & Skill test & $\begin{array}{l}\text { Measurem } \\
\text { ent unit }\end{array}$ & $\begin{array}{l}\text { Mean of pre } \\
\text { measurement }\end{array}$ & $\begin{array}{l}\text { Mean of post } \\
\text { measurement }\end{array}$ & $\begin{array}{l}\text { Standard } \\
\text { deviation } \\
\text { difference }\end{array}$ & $\begin{array}{l}\text { Differences } \\
\text { mean }\end{array}$ & $\begin{array}{l}\text { Ca } \\
\text { lculated } \\
\text { [T] value }\end{array}$ \\
\hline 2 & $\begin{array}{l}\text { Accuracy of } \\
\text { passing from } \\
\text { the top on the } \\
\text { wall }\end{array}$ & $\begin{array}{l}\text { Passing from } \\
\text { the bottom on } \\
\text { the wall for } \\
30 \text { seconds }\end{array}$ & 20,83 & 25,30 & 1,47 & 4,47 & 14,254 \\
\hline 3 & $\begin{array}{l}\text { AAPHER test } \\
\text { for sending } \\
\text { from degree } \\
\text { bottom the }\end{array}$ & 18,43 & 22,97 & 2,65 & 4,53 & 9,37 \\
\hline
\end{tabular}

The tabular [t]value at the level $(0,05)=1,68$ 
Table (6) shows that there are statistically significant differences between the mean of the pre and the post measurement degrees in the experimental group in the skill tests favoring

Table (7) post measurements, where the calculated [t] is higher than the tabular [ $\mathrm{t}$ value at the level $(0,05)$.

Significance of differences between the means of the pre and post measurements degree in the control group in the skill tests

$$
\mathrm{N}=60
$$

\begin{tabular}{|l|l|l|l|l|l|l|}
\hline Skill test & $\begin{array}{l}\text { Measurement } \\
\text { unit }\end{array}$ & \multicolumn{2}{l|}{$\begin{array}{l}\text { Experimental } \\
\text { group }\end{array}$} & \multicolumn{2}{l|}{ Control groups } & \multicolumn{2}{l|}{$\begin{array}{l}\text { Calculated } \\
\text { [T] value }\end{array}$} \\
\hline $\begin{array}{l}\text { 1-curacy of passing from the top on } \\
\text { the wall }\end{array}$ & degree & 27,70 & 1,02 & 25,30 & 0,88 & 9,59 \\
\hline $\begin{array}{l}\text { 2-ssing from the bottom on the wall } \\
\text { for 30 seconds }\end{array}$ & degree & 24,73 & 0,74 & 22,97 & 1,33 & 6,23 \\
\hline $\begin{array}{l}\text { 3-PHER test for sending from the } \\
\text { bottom }\end{array}$ & degree & 29,03 & 1,02 & 26,10 & 0,55 & 11,40 \\
\hline
\end{tabular}

The tabular [t]value at the level $(0,05)=2,021$

Table (7) shows that there are statistically post measurements, where the calculated [t]is significant differences between the mean of the higher than the tabular [t]value at the level pre and the post measurement degrees in the $(0,05)$.

experimental group in the skill tests favoring

Table (8)

Percentage change in the control and experimental groups in the skill tests

$$
\mathrm{N}=60
$$

\begin{tabular}{|l|l|l|l|l|l|l|l|}
\hline Skill test & \multicolumn{2}{|l|}{$\begin{array}{l}\text { Measurement } \\
\text { group }\end{array}$} & \multicolumn{2}{|l|}{$\begin{array}{l}\text { Experimental } \\
\text { group }\end{array}$} & \multicolumn{2}{l|}{$\begin{array}{l}\text { Percentage } \\
\text { change \% }\end{array}$} & \multicolumn{2}{l|}{$\begin{array}{l}\text { Control } \\
\text { groups }\end{array}$} & \multicolumn{2}{l}{$\begin{array}{l}\text { Percentage } \\
\text { change \% }\end{array}$} \\
\hline $\begin{array}{l}\text { 1-curacy of passing } \\
\text { from the top on the } \\
\text { wall }\end{array}$ & Degree & 20,08 & 27,70 & 33,17 & 20,83 & 25,03 & 21,46 \\
\hline $\begin{array}{l}\text { 2-ssing from the } \\
\text { bottom on the wall for } \\
30 \text { seconds Degree }\end{array}$ & 18,37 & 24,73 & 34,62 & 18,43 & 22,97 & 24,63 \\
\hline $\begin{array}{l}\text { 3-PHER test for } \\
\text { sending from the } \\
\text { bottom Degree }\end{array}$ & 201,17 & 29,03 & 43,93 & 20,03 & 26,10 & 30,30 \\
\hline
\end{tabular}

The tabular [t] value at the level $(0,05)=2,021$.

Table (8) shows that percentage change in the experienced group is higher than in the control group in the skill tests. 
Table (9)

Significance of differences between the mean of the pre measurement and the post measurement degrees in the experimental group in the cognitive acquisition test

$$
\mathrm{N}=30
$$

\begin{tabular}{|l|l|l|l|l|l|l|}
\hline Test & $\begin{array}{l}\text { Measurement } \\
\text { unit }\end{array}$ & $\begin{array}{l}\text { Mean pre- } \\
\text { measurement }\end{array}$ & $\begin{array}{l}\text { Mean of post } \\
\text { measurement }\end{array}$ & $\begin{array}{l}\text { Differences } \\
\text { standard } \\
\text { deviation }\end{array}$ & $\begin{array}{l}\text { Differences } \\
\text { mean }\end{array}$ & $\begin{array}{l}\text { Calculate } \\
\text { [t] value }\end{array}$ \\
\hline $\begin{array}{l}\text { Cognitive } \\
\text { acquisition }\end{array}$ & Degree & 13,30 & 27,03 & 1,76 & 13,73 & 42,73 \\
\hline
\end{tabular}

The tabular $\mathrm{t}$ value at the level of $0,05=1,68$.

Table (9) shows that there are statistically test favoring post measurements, where the significant differences between the mean of the pre and the post measurements degrees in the experimental group in the cognitive acquisition calculated $[\mathrm{t}]$ value is higher than the tabular $\mathrm{t}$ value at the level of 0,050 .

Table (10)

Significance of differences between the means of the pre and post measurements degrees in the control group in the cognitive acquisition

$$
\mathrm{N}=30
$$

\begin{tabular}{|l|l|l|l|l|l|l|}
\hline Test & $\begin{array}{l}\text { Measurement } \\
\text { unit }\end{array}$ & $\begin{array}{l}\text { Mean of pre } \\
\text { measurement }\end{array}$ & $\begin{array}{l}\text { mean of post } \\
\text { measurement }\end{array}$ & $\begin{array}{l}\text { Differences } \\
\text { standard } \\
\text { deviation }\end{array}$ & $\begin{array}{l}\text { difference } \\
\text { mean }\end{array}$ & $\begin{array}{l}\text { Calculated } \\
\text { [t] value }\end{array}$ \\
\hline $\begin{array}{l}\text { Cognitive } \\
\text { acquisition }\end{array}$ & Degree & 13,23 & 23,73 & 1,91 & 10,50 & 30,15 \\
\hline
\end{tabular}

The tabular $t$ value at the level of $0,05=1,68$.

Table (10) shows that there are statistically significant differences between the mean of the pre and the post measurement degrees in the experimental group in the skill test favoring post

Table (11)

Significance of differences between the mean of the two post measurements degrees for the control and experimental group in the cognitive acquisition test

$$
\mathrm{N}=60
$$

\begin{tabular}{|l|l|l|l|l|l|l|}
\hline Test & $\begin{array}{l}\text { Measurement } \\
\text { unit }\end{array}$ & \multicolumn{2}{|l|}{$\begin{array}{l}\text { Experimental } \\
\text { group }\end{array}$} & $\begin{array}{l}\text { Percentage } \\
\text { change }\end{array}$ & $\begin{array}{l}\text { Control } \\
\text { groups }\end{array}$ & $\begin{array}{l}\text { Percentage } \\
\text { change }\end{array}$ \\
\hline $\begin{array}{l}\text { Cognitive } \\
\text { acquisition }\end{array}$ & Degree & 27,03 & 1,13 & 23,73 & 1,08 & 11,37 \\
\hline
\end{tabular}

The tabular[t]value at the level $(0,05)=2,021$. 
Table (11) shows that there are statistically significant differences between the means of the two post measurement degrees in the cognitive

\section{Table (12)}

Percentage change in the control and experimental groups in the cognitive acquisition test

$$
\mathrm{N}=60
$$

\begin{tabular}{|l|l|l|l|l|l|l|}
\hline Test & \multicolumn{2}{|l|}{$\begin{array}{l}\text { Experimental } \\
\text { group }\end{array}$} & $\begin{array}{l}\text { Percentage } \\
\text { change\% }\end{array}$ & \multicolumn{2}{l|}{ Control groups } & $\begin{array}{l}\text { Percentage } \\
\text { change }\end{array}$ \\
\hline $\begin{array}{l}\text { Cognitive } \\
\text { acquisition }\end{array}$ & 13,30 & 27,03 & 103,23 & 13,23 & 23,73 & 79,37 \\
\hline
\end{tabular}

The tabular [t] value at the level $(0,05)=2,021$.

Table (12) shows that there are percentage in the cognitive acquisition test favoring the changes in the experimental and control groups experimental group.

\section{Table (13)}

The emotional side of the students in the experimental group toward Using the computerized systematic approach in learning volleyball

$$
\mathrm{N}=30
$$

\begin{tabular}{|l|l|l|l|l|l|l|l|}
\hline $\begin{array}{l}\text { Phrase } \\
\text { Number }\end{array}$ & $\begin{array}{l}\text { Agree } \\
\text { Strongly }\end{array}$ & $\begin{array}{l}\text { Not } \\
\text { sure }\end{array}$ & $\begin{array}{l}\text { Disagree } \\
\text { Strongly }\end{array}$ & $\begin{array}{l}\text { Relative } \\
\text { weight }\end{array}$ & parentage & $\begin{array}{l}\text { K2 } \\
\text { Ka }\end{array}$ & $\begin{array}{l}\text { Significance } \\
\text { Level }\end{array}$ \\
\hline 1 & 26 & 2 & 2 & 84 & 93.33 & 38.40 & Significant \\
\hline 2 & 25 & 3 & 2 & 83 & 92.22 & 33.80 & Significant \\
\hline 3 & 3 & 5 & 22 & 79 & 86.78 & 21.80 & Significant \\
\hline 4 & 24 & 3 & 3 & 81 & 90.00 & 29.40 & Significant \\
\hline 5 & 26 & 4 & 5 & 86 & 95.56 & 39.40 & Significant \\
\hline 6 & 1 & 4 & 25 & 84 & 93.33 & 34.20 & Significant \\
\hline 7 & 20 & 6 & 4 & 76 & 84.44 & 15.20 & Significant \\
\hline 8 & 4 & 4 & 22 & 78 & 86.67 & 21.60 & Significant \\
\hline 9 & 21 & 6 & 3 & 78 & 86.67 & 18.60 & Significant \\
\hline 10 & 3 & 4 & 23 & 80 & 88.89 & 25.40 & Significant \\
\hline 11 & 23 & 5 & 2 & 81 & 90.00 & 25.40 & Significant \\
\hline 12 & 20 & 5 & 5 & 75 & 83.33 & 15.00 & Significant \\
\hline 13 & 0 & 6 & 24 & 84 & 93.33 & 31.20 & Significant \\
\hline 14 & 25 & 5 & 0 & 85 & 94.44 & 35.00 & Significant \\
\hline 15 & 23 & 4 & 3 & 80 & 88.89 & 25.40 & Significant \\
\hline
\end{tabular}

The tabular ( Ka2) at the level ( 0.05) =5.99

Table (13) Shows that the Students' emotional Side in the experimental group to wards the phrases of the emotional measurement is statistically significant at the level of 0.05 . This indicates that using the computerized systematic approach in learning volleyball skills has a positive effect on the students' Emotional Side in the experimental group. 


\section{Discussion}

Table (7) shows that there are statistically significant differences at the level of 0.05 between the means of the two post measurements degrees in the experimental and control groups in the skill tests favoring the experimental group, where the calculated $(\mathrm{T})$ value is higher then the tabular $(\mathrm{T})$ value .

Researchers attribute the progress of the students in the experimental group on the students of the control groups when they learned volleyball skills to using the systematic approach software with its varied audio and visual facilities, watching the skills in a unified and direct way simplified students' learning of volleyball skills students' interaction with the computer simplified learning and encouraged learners to gain the sporty motional kills and their motional conception. This agrees with that Mohamed Saad, Makarem Aboharga and Hany Said referred to (2001). They said that visual processes and using feedback have a positive effect on building and developing motional conception, improving performance and fast learning. Learning Technology in the field of physical Education helps to perform the visual skill in the a unified way for all learners, so it helps to evaluate its understanding instead of showing it by more human models including various ways of performance $(36: 22,23)$.

This also agrees with what Nesreen Ali (2005) finding that using the systematic approach helped learners understand the major concepts that are related to skills and showing them in a systematic way that increased the ability to use them accurately in practice, fulfilling these basic skills learning, and the positive effect on the skill level and increased the motivation of learning ( $43: 95$ ).

Researchers also attribute the progress of the experiment group students on the students of the control groups to using the computerized systematic approach which caused a progress in the skill level of volleyball, because it helped the students to know the basic concepts of these skills in the light of research, showing them in a systematic way that determines the relation between the skills and concept through the computerized show, and connecting them with the previously learned skills to be used completely in the applied activity. This complies with what Basma Morsy referred to (2009)(13) in the outcomes of her study showing that the systematic approach has a positive effect on the skill level more than the traditional method.

So the first hypothesis which indicates that there are statistically significant differences between the means of the two post measurements for the control and experiment groups in learning volleyball skills favoring the experimental group, was confirmed.

Results of table (8) show that there are differences in the percentage change between the pre and post measurement degrees in the control and experiments groups in skill tests favoring the experimental group.

Percentage change of the experimental group that used the systematic approach software ranged between $33.17 \%$ and $13.93 \%$, but the control group that used traditional way ranged between $21.46 \%$ and $30.30 \%$, but the percentage change in the skill tests, accuracy of passing from the top on the wall, passing from the bottom on the wall for thirty seconds, AAPHER test for sending from the bottom was as follows: $(33.17 \%, 34.62 \% .43 .93 \%)$ in the experiments groups, while the percentage change in the control groups in the same skill tests was as follows: $(21.46 \%, 24.63 \%$, $30.30 \%$ ), therefore the highest improvement percentage in the skill tests was in the experiment group. Researches suggest that using the systematic approach software caused this improvement in view of its positive effect on learning volleyball skills in the light of research.

Researchers attribute these differences to the experimental variable which used the systematic approach since it enabled students to know the main concepts related to volleyball skills, showing them in a systematic way that determines the relations between skills and concepts, and increasing the ability to use them accurately in practice. This leads to a full learning of these skills as they represent for the leaner connected and interacted experience that can be applied easily.

These results comply with results of the studies by Nesreen Ali (2005)(43), Eman Mohammed (2007)(12), Basma Morsi (2009)(13) and 
Ibtesam Ali (2010) (1) which used the systematic approach, and indicated that it enables student to develop their skills from the easy one to the difficult, and from the simple to the complex. This helps achieve the skill aims. Thus the seconds hypothesis which stated that percentage change of the experimental group is higher than that of the control group in learning volleyball skills.

The results of table (11) show that there are statistically significant differences between the degrees in the control and experimental groups in the cognitive acquisition test favoring the experimental group, where as the calculated (T) value is higher than the tabular (T) value.

Researchers attribute the progress of the students in the experimental on the students in the control groups in the cognitive acquisition test of the volleyball skills in the light of research to using the systematic approach software including information related to the side of historic development, some legal features, the educational and technical parts in volleyball skills in the night of research. The computerized systematic approach connected between the learners new and old concepts and creating the ability to think in a distinct systematic way, this led to achieving one of learning aims (cognitive side) in a progressive way.

In this context Ameen Farouk Fahmy and Mona Abdalsabour (2001) indicate that the systematic approach is used in teaching process from the beginning to the end of the subject. At the beginning of the subject, it's used to connect the new concepts with the cognitive storage in learner's cognitive structure. It's used continuously during studying the subject to explain the mutual relation between the different concepts inside the systematic approach Also it is used at the end of studying the subject to connect the concepts, show the relation between them and distinguishing between them. In addition, it develops the student's ability to use the concepts in new situations match his understanding of the subject, this will help to develop the systematic thinking which id one of the most important uses of systematic approach in learning and education $(11: 63)$.
This agrees with the results of Nesreen Ali (2005)(43), Bassma Morsi (2009) (13), Amani Rafaat, Alsayed Sami and Sali Ibrahim (2010) (9) which showed that the systematic approach has a positive effect on learners "cognitive level".

Researches attribute the progress of the students in the experimental group on the students of the control groups to the computerized systematic approach that includes much information related to volleyball skills in the light of research. Computerized systematic approach increased learners motive towards learning, it considered the individual differences between learning, it considered the individual differences between learners. It helped in providing the sides of learning in general and the cognitive side in particular group didn't get this as their cognitive acquisition was traditional.

Hence, the third hypothesis which stated that there are differences with statistical significance between the means of the two post measurement degrees for the control and experimental group in the cognitive acquisition of volleyball skills in the light of research and in favor of the experimental group become true.

Also the results of table (12) showed that there are difference in the percentage change between the mean of the pre and post measurements degrees for the control and experimental group in the in the cognitive acquisition test in the light of research and in favor of the experimental group tat used a computerized systematic approach was $\% 103.23$ but it was $\%$ 79.37 for the control groups which used a traditional way, so the highest percentage of improvement in the cognitive acquisition test was in favor of the experimental group. Researchers see that this the systematic approach that had appositive effect on the cognitive acquisition of volleyball skills in the light of research, this agrees with the study results of Nesreen Ali (2005) (43), Bassma Morsi (2009) (13), and Ibtesam Ahmed Mohamed (2010) (1).

Researchers see that the improvement in the cognitive acquisition test for the student of the experimental group resulted from showing the material and organizing the content of volleyball curriculum by using the systematic approach and providing it to the learners in a 
form of interacting relation that help them to draw a mental map that organizes their cognitive building, enable them to learn and increase cognitive acquisition. This took place also because of reorganizing the content and the learner's activity, Besides starting with the complete things then the divided things, there isn't a random connection between the stimuli and responses. In addition to preparing a curriculum for volleyball by using the systematic approach in the light of educational objectives that are set clearly and accurately, that what Fawzy Ahmed Zaher (1979)(31) refered to he indicated that setting the educational objectives accurately enables the learner to know what's expected from him, this makes him concentrated on achieving his aims.

So we find that the computerized systematic approach provided the students of the experimental group with the curriculum, and increased their attention in the cognitive acquisition of volleyball curriculum and helped them to achieve the certain educational aims. This shows the effect of the systematic approach on achieving the cognitive aims.

Consequently the fourth hypothesis which stated that the percentage change of the experimental group is higher than the control groups in the cognitive acquisition of volleyball skills in the light of research was confirmed.

Results of table (13) showed that the students, responses in the experimental group towards the phrases of the emotional side measurement had a statistical significance at the level (0.05), this is a good in target for using the computerized systematic approach in achieving the emotional side. Researchers attribute the positive opinions and impressions about the systematic approach in the experimental group to its success in removing feeling boredom and negativity towards the traditional methods in teaching. It considers the individual differences between learners and their different abilities. Also it draws their attention and motivates them. This encouraged the students of the experimental group to use the computerized systematic approach. This agrees with the study results of Hiatham Abdalmageed (2005) (45) and Asmaa Ahmed Mohemd (2009) (6).

Researchers attribute the progress of the experimental group students in the emotional side to using the computerized systematic approach in learning volleyball skills in the light of the research. Volleyball is a source of pleasure, fun, zeal and self confidence. It's a team game that students love because of the challenge and competition that it has. This results in getting the main and motional skills easily and makes the students do their best to achieve their tasks without feeling bored.

Nezar Alzeen (1989) (42), Ali Moustafa (1999) (30) and Zaki Hassan (2003) (16) clarify that it's easy to learn volleyball and develop in playing it as it's simple, both genders can play it, it's not restricted to a certain age. In addition, it it's can benefit all parts of the body. It has many benefits and characteristics such as improving functional fitness, developing and promoting physical fitness, learning basic, planning and motional skills. It's a rich field for mental abilities such as attention, consciousness, understanding, concentration, intelligence acquisition, keeping plans and the ability to carry out them.

Ameen Farouk Fahmy and Mona Abdalsaour (2001) (11) refer to the importance of caring about all sides of learning [cognitive, psychological and motional] in a comprehensive and interactive way in order to Have citizens who has good positive personality able to give, work, renew, create and think in systematic way. Using the computerized systematic approach in teaching and learning volleyball skills improved the students, emotions and their aims.

Consequently, the fifth hypothesis which stated that there are statistically significant differences in the students' emotional side in the experimental group towards using the computerized systematic approach in learning volleyball skills was confirmed.

\section{Conclusion}

1- Teaching by using the computerized systematic approach has a positive effect and is more effective in the teaching process, as it resulted in the excellence of the experimental group in the cognitive acquisition test for the volleyball curriculum. 
2- The experimental group surpassed the control groups in all skill tests in the light of research.

3- Learning by using the computerized systematic approach has a positive effect on developing the emotional side as it increased the students' motivation and efficacy towards learning volleyball.

\section{Recommendations}

1- Using the systematic approach in teaching and learning volleyball because of its positive effect on learning.

\section{References}

\section{Arabic references}

1- Ibtesam Mohamed Ali (2010): the efficacy of the International law and basketball skills in the light of the systematic approach effect on learning for the female students in faculty of physical education, Doctorate thesis, Faculty of physical education, females, Alexandria University.

2- Ahmed Alsayed Al Mowafi (1999): the effect of using some teaching methods on learning some volleyball skills for the students in faculty of physical education, master thesis, faculty of physical education for boys, Al Zakazik, Al Zakazik University.

3-Ahmed Khodari Mohamed (2010): How is volleyball.

4- Ahmed Mohamed Abd AlAziz (2010): the effect of educational program using three dimensional drawings on learning gymnastics skills for the students of grade Two in primary education Doctorate thesis, faculty of physical Education, Al-Minya University.

5- Osama Ahmed Abd Al Aziz (2001): The effect of educational program using hypermedia on learning the competition of high Jump for beginners, Master Thesis, Faculty of physical Education, Al-Minya University.

6- Asmaa Ahmed Mohamed (2009): Building a system for teaching efficiency to prepare the female student / teacher in Alexandria faculty of physical Education, analytical descriptive study for water Sports, Master thesis, faculty of physical education for girls, Alexandria University.

7- Eleen Wadi Farag (1990): volleyball, guidance for teacher, trainer and player, Knowledge institution, Alexandria.

8- Eleen Wadi Farag (2004): Basics of volleyball training for juniors, Knowledge institution, Alexandria

9- Amani Refaat AlBahiri, Alsayed sami salah, and Sali Ibrahim Nabil (2010): the effect of using the systematic approach on learning some skills of duel for Juniors under thirteen years, published research, the Scientific conference on the Arab Universities sports, prospects and horizons, Egypt. 
10- Ameen Farouk Fahmy and Gola Goxy (2000): The systematic attitude in Teaching and learning in the 2lst century, modern Arab institution, Egypt.

11- Ameen Farouk Fahmy and Mona Abd Al Sabour (2001): The systematic approach in facing the future and contemporary educational challenges, Knowledge house, cairo.

12- Eman Mahmoud Mohamed (2007): Developing the motional Expression curriculum in Alexandria faculty of physical education for girls in the light of the systematic approach, Doctorate thesis, Faculty of physical Education for girls, Alexandria University.

13- Bassma Mahmoud Morsi (2009): the efficacy of using the organized system in learning some basic skills for table Tennis, Master thesis, Faculty of physical Education, Alexandria university.

14- Zaki Mohamed hassan (1998): volleyball building planning and technical skill, knowledge institution, Alexandria

15- Zaki Mohamed Hassan (2007): Volleyball modern techniques in technical and education, thought meeting, Alexandria

16- Zaki Mohamed Hassan (2003): Methods of teaching Volleyball (education, teaching, practice, evaluation, primary plans and law)

Al Shanbahani Institution, Alexandria.

17-Zaki Mohamed Hassan (2007): Volleyball, planning and skill sides, Al Shanbahani Institution, Alexandria

18- Tarek Mohamed Abd Al Aziz and Ayman Abdo Mohamed (2006): The effect of educational program by using computer on the students, skill and cognitive acquisition in volleyball, faculty of physical education, Assuit university.

19- Abd Alat.. Abd Al Fatah Al Sayed (1996): Volleyball for all (learning training - Plans - Law), Egypt Merna Library, Al Mansoura.

20- Abd Al Azeem Abd Al Salam Al Faragani (2002): Technology and developing education, Gharib house for publishing, printing and distribution, Cairo.

21-Abd Allah Moahmed Ibrahim (2003): Applying the systematic attitude in teaching and learning biological sciences, published research, the first Arab conference on the systematic approach in teaching and learning, center of developing sciences teaching, Ain Shams University, February 17,18.

22- Othman Moustafa Othman, (2001): the effect of using different methods in practice by the peers guidance on learning some basic skill of volleyball published research, Magazine of sports Sciences, Volume 13, half year issue, Faculty of physical education Al-Minya University, September - December.

23- Othman Mustafa Othman and Nasser Mustafa Sayed (2005): the efficacy of using the method of different levels stations on some healthy, skill, physical variables, and the meaning of physical ego in physical Education, lesson, published research, Assuit Magazine for Sciences 
and arts of physical Education, Issue Twenty, part two, half year issue, Faculty of physical Education, Assuit University.

24- Othman Mustafa Othman and Hisham Mohamed Abd Al Haleem (2003): the effect of educational program by using computerized cartoons on learning some motional skills in physical education lesson for grade one students in primary education, published research, application and theories Magazine, Forty eighth issue, Faculty of physical education for boys, Alexandria University.

25- Essam Al Weshahi (1983): volleyball for juniors and schools students, Arab thinking House, Cairo.

26- Essam Al Weshahi (1991): Educational principles in volleyball, Arab thinking house, Cairo.

27- Essam Al Weshahi (1994): modern volleyball, how to reach the world level, Arab thinking House, Cairo.

28- Afaf Ahmed Tawfik and Azza Omar Abd El Haleem (1988): Comparative study for the efficacy of two methods of teaching methods for the cognitive and skill level in volleyball. Published research. Applications and theories Magazine Fourth issue Alexandria Faculty of physical Education for girls, Helwan University.

29- Alaa Aldeen mohamadi Abd Al Hameed (2009): The effect of a program suggested by electronic games on learning some basketball skills and developing the inconstant creation for primary stage students. Doctorate thesis, Faculty of physical Education Al- Minya University.

30- Ali Mustafa Taha (1999): volleyball [history - learning - training - analysis law] Arab Thinking House, Cairo.

31- Fawzi Ahmed Zaher (1979) Designing programs and developing teaching methods, Educational Technology Magazine, The Arab Center for Educational techniques, Third issue, Kiwait.

32- Foad Albahi Al Sayed (1979): Statistical psychology and measuring human mind, Arab thinking House, Cairo .

33- Kamal Abd Al Hamed and Mohamed Sobhi Hassanein (1997): Fitness and its elements (heoretical basics. Physical preparation . Measurement methods) Arab thinking House, Cairo .

34-Mohamed Bodr Al deen Saleh (2006): Designing a Computerized program for teaching some skill of volleyball - Doctorate thesis, faculty of physical Education - Banha University.

35- Mohamed Hassan Alawi and Mohamed Nasr Al Deen Redwan (1994): Tests of motional performance Arab Thinking House, Cairo .

36- Mohamed saad Zaghlool, Makarem Helmy Abo Harja and Hani said Abd Al Monem (2001): Education, technology and its methods in physical Education, Book center for publishing, Cairo.

37- Mohamed Sobhi Hussaneen (2004): measurement and evaluation in physical Education, Arab thinking House, Cairo .

38- Moahmed Sobhi Hassaneen and Hamdy Abd Al Monem (1997): Scientific basics for volleyball. And measurement methods of evaluation 
(physical - skilful - cognitive - psychological - analytical) book center for publishing, Cairo.

39- Mohamed fahmy Tolba (2004): Workshop about the systematic approach and distance learning, The Fourth Arab conference on the systematic Attitude in Learning and teaching, Teaching Development Center, Ain Shams university ,3-4 April.

40- Mustafa Al- sayed Mohamed (2004): the technological curriculum, Education and information Technology in physical Education, Al Wafa House for printing and publishing - Alexandria.

41- Mustafa Alnobi Mohamed (2009): the efficacy of systematic approach in developing volleyball curriculum in faculty of physical Education, published Reseoarch, the fourth Scientific Conference on modern trends for physical sciences in the light of work market. Faculty of rhysical Education, Assuit University.

42- Nezar Alzeen (1989): volleyball [ training - learning ] The Arab thinking House Beirut - Lebanon .

43- Nesreen Ali Mohamed (2005): The efficacy of systematic approach in learning some basic skills of handball for the female students of Alexandria Faculty of physical Education. Master Thesis Faculty of physical Education for girls - Alexandria University

44- Nasema Mahmoud Ibrahim (1986): the effect of using the guiding individual teaching Strategies for learning throwing in volleyball, Master thesis Faculty of physical Education for girls, Alexandria University.

45- Haitham Abd Al Mageed Mohamed (2005): The effect of the fourth mutual application by using computer on the irritating, cognitive and skilful skills in fencing for students in Al- Minya Faculty of physical Education, Doctorate thesis, Faculty of physical Education Al Minya University.

46- Wafeka Mustafa Hassan (2001): Technology of learning and Educational in Physical Education Knowledge institution, Alexandria

47- Yousef Salahaldeen Kotb (1998): systematic approach in planning for developing and reforming education, fourth issue, may.

\section{Foreign References:}

48- Banathy, B (1991): system design of education Ajourney to create the future : Englewood cliffs Education Technology publisher.

49- carol, D other (1977): A systematic approach to creating and implementing curricular innovation, paper presented at the University council for education administration, Or Lando, Fl, November, ed418065.

50- Fontain .c Wood. J. (2000): A systems approach to Understanding and counseling college - student athletes, journal of college counseling, 6(1) 35-45, department of special education University of TexasAustin

51- Harmons, Hirumi and A (1996): A systematic approach to the integration and training Journal of education for businss: May / June :7(5) 
52- Kaufman, R (1993): Beyond tinkering: education restructuring that eill work " international journal reform:2(2)

53- Yeager, R. (1991): The systematic learning models, the Science teacher, ed. 401802 